\title{
Grensen. En reise rundt Russland gjennom Nord-Korea, Kina, Mongolia, Kasakhstan, Aserbajdsjan, Georgia, Ukraina, Hviterussland, Litauen, Polen, Latvia, Estland, Finland og Norge samt Nordøstpassasjen
}

\author{
Erika Fatland \\ Oslo: Kagge Forlag AS 2017 \\ 623 sider. ISBN 9788248921493
}

Omtalt av Martin Haaskjold Inderhaug [MA i politikk, økonomi og filosofi fra Higher School of Economics (HSE), martinderhaug@gmail.com]

I februar 2014 hadde Erika Fatland en drøm der hun gikk på et kjempestort kart langs en rød strek fra land til land. På den ene siden av den røde streken var Russland - verdens største land. Da hun våknet skjønte hun at denne drømmen skulle bli virkelighet, men først måtte hun sjekke om boken allerede var skrevet. Til hennes store forbauselse fantes det ingenting tilsvarende på Amazon. Rundt tre år senere, hvorav 259 dager var på reisefot, hadde det som startet som en drøm - blitt til en bok.

Boken er et ambisiøst og omfattende verk, både intellektuelt og rent praktisk. For det første er det fjorten svært forskjellige land som det berettes fra, noen er land med flere tusen års historie, mens andre er stater som først ble selvstendige ved oppløsningen av Sovjetunionen for knappe 30 år siden. Reiseskildringene trekker således frem unike historiske fakta vedrørende geografi, økonomi, kultur og politikk, i tillegg til en beskrivelse av nåtiden, for hvert av landene.

Historiebiten legger et viktig grunnlag for å gjøre leseren i stand til å forstå og tolke skildringene av dagens situasjon. Den store utfordringen for Fatland ligger i å plukke ut hvilke historiske betraktninger som er relevante å trekke frem. Dette er ingen enkel oppgave, og en del av historieopplysningene kan derfor fremstå som noe tilfeldig utvalgt. Det kan også i enkelte tilfeller bli litt mye informasjon, for eksempel er tjue sider om den finske feltmarskalken Mannerheim gjerne først og fremst egnet for de spesielt interesserte. 
Styrken i boken ligger i at Fatland evner å dra leseren med inn i reiseopplevelsen. For selv om mange av landene hun besøker anses for å være eksotiske og spesielle, kunne det fort ha blitt en tørr bok dersom Fatland bare hadde oppsøkt minnesmerker og turiststeder. Erika Fatland er utdannet sosialantropolog, noe som kommer godt med på reisen. Hun evner å bli kjent med menneskene hun møter, og beskriver opplevelsene på en realistisk måte. På denne måten blir man som leser $\mathrm{i}$ stand til å leve seg inn i situasjonene, og dette er en viktig årsak til at boken blir spennende. Denne effekten kommer best frem i Asia og i Kaukasus-delen, mens Fatland i Europa ikke finner en like god balanse mellom fakta- og historieopplysningene på den ene siden, og de mer personlige skildringene av møtene med de «innfødte» på den andre siden.

Den første etappen på Russlands 60932 kilometer lange grense (som for øvrig er lengre enn jordens omkrets), går fra Anadyr ved Beringstredet helt i øst, gjennom nordøstpassasjen, til Murmansk. Her mønstrer Fatland på en gammel sovjetisk forskningsbåt sammen med 47 rike globetrottere og hennes observasjoner av det enorme arktiske landskapet er forfriskende lesning. Deretter deles boken i tre: Asia med Nord-Korea, Kina, Mongolia, Kasakhstan, Kaukasus med Aserbajdsjan og Georgia, og Europa med Ukraina, Hviterussland, Litauen, Polen, Latvia, Estland, Finland og til slutt Norge.

Fatland snakker åtte språk, deriblant russisk, hindi og arabisk. Med unntak av i Kina, kunne hun kommunisere med de aller fleste menneskene hun møtte. I landene mellom Kazakhstan og Estland kan de fleste snakke russisk, selv om de har sine nasjonale språk. Dette fordi de tidligere var en del av Sovjetunionen. Hvordan stedene hun besøker har blitt påvirket av å ha Russland som nabo er bokens røde tråd, og svarene på dette varierer ikke bare mellom de fjorten ulike landene, men også fra sted til sted innad i landene. Da Sovjetunionen kollapset og ble oppløst i nasjonalstater, forsvant nesten en tredjedel av territoriet til Russland - unionens ideologiske og maktmessige kjerne og dermed også unionens «etterfølger». Halvparten av Sovjetunionens befolkning våknet nærmest på en natt, opp i «nye» land utenfor Russland. Enkelte av disse nye landene var områder som hadde vært del av Russland i århundrer, og hvor deler av befolkningen identifiserte seg som russere. Mens oppløsningen av Sovjetunionen for mange sovjetborgere representerte en drøm om selvstendighet som endelig gikk i oppfyllelse, ble det av andre oppfattet som en drøm som gikk tapt. Av sistnevnte gruppe flyttet mange til Russland, mens andre valgte å bli boende i sitt nye land, dog uten å gi slipp på sin russiske identitet. Dette er et viktig bakteppe for de ulike oppfatningene om Russland langs landets grenseområder.

Med unntak av Norge har alle de andre grenselandene vært i krig med eller blitt invadert av Russland. Enten det er snakk om tsarimperiet, Sovjetunionen eller dagens «Putin-Russland» synes mønsteret å være det samme: Russland er en truende nabo. Mellom bokens reiseskildringer og historiefortellinger finner man også flere betraktninger av mer politisk natur. Dessverre blir disse ofte fremstilt som udiskutable sannheter, som tydelig er farget av at boken er skrevet fra et vestlig ståsted. Det 
som kjennetegner dagens konflikt mellom Russland og Vesten, er at fiendebildene av hverandre ikke bare speiler "objektive fakta», men i større grad styres av narrativer, historiefortolkninger og geopolitiske allianser. Forfatteren legger ofte til grunn det vestlige narrativet som «det sanne», og det er både legitimt og forståelig. Men samtidig ligger det en fare her. For hvordan ville bokens totalinntrykk vært, dersom den hadde vært skrevet av en forfatter som i stedet hadde lagt et russisk narrativ til grunn? Dette kan være en interessant mental øvelse, som boken dessverre ikke evner å få frem. Samtidig har den heller ikke ambisjoner om det, og tar man det i betraktning, er boken totalt sett både interessant, lærerik og spennende. 